\title{
ANALISIS PENGETAHUAN PEREMPUAN TERHADAP PERILAKU MELAKUKAN PERNIKAHAN USIA DINI DI KECAMATAN WONOSARI KABUPATEN BONDOWOSO
}

\author{
Intan Arimurti, Ira Nurmala \\ Departemen Promosi Kesehatan dan Ilmu Perilaku, Fakultas Kesehatan Masyarakat \\ Universitas Airlangga, Kampus C Mulyorejo Surabaya, Jawa Timur - 60115 \\ Email: intanarimurtii@gmail.com
}

\begin{abstract}
One of the problems that still exist in Indonesia was early marriage. Early marriage was a marriage under years old 18 (UNICEF, 2014). Early marriage can be caused by many factors liked the knowledge by women who do early age and her parents. The purpose of this study was to analyze of knowledge of women on the attitude of early marriage in Wonosari, Bondowoso District. This research was a descriptive research using qualitative approach, conducted in Wonosari, Bondowoso District. Researchers use a purposive way to determine the subject to be studied. Based on research results, low knowledge of early marriage in women has a relationship with the low education of parents, family, environment, mass media, experience about early marriage and the impact on health. Based on the results of the study could be concluded that the lower of knowledge of women have higher attitude of tendency early marriage than higher knowledge.
\end{abstract}

Keywords: knowledge, early marriage, factors, parents

\begin{abstract}
ABSTRAK
Salah satu permasalahan yang masih ada di Indonesia adalah pernikahan usia dini. Pernikahan usia dini merupakan pernikahan yang dilakukan dibawah usia 18 tahun (UNICEF, 2014). Pernikahan usia dini dapat disebabkan oleh banyak faktor yang memengaruhi salah satunya adalah pengetahuan yang dimiliki oleh perempuan yang melakukan usia dini serta orang tuanya. Tujuan penelitian ini adalah menganalisis pengetahuan perempuan terhadap sikap melakukan pernikahan usia dini di Kecamatan Wonosari Kabupaten Bondowoso. Penelitian ini merupakan penelitian deskriptif dengan menggunakan pendekatan kualitatif, yang dilakukan di Kecamatan Wonosari Kabupaten Bondowoso. Peneliti menggunakan cara purposive untuk menentukan subjek yang akan diteliti. Berdasarkan hasil penelitian, rendahnya pengetahuan tentang pernikahan usia dini pada perempuan memiliki hubungan dengan rendahnya pendidikan orang tua, keluarga, lingkungan, media masa, pengalaman tentang pernikahan usia dini dan dampak bagi kesehatan. Berdasarkan hasil penelitian sikap memiliki kecenderungan dapat disimpulkan bahwa semakin rendahnya pengetahuan perempuan tentang pernikahan usia dini maka sikap kecenderungan menikah di usia dini semakin tinggi.
\end{abstract}

Kata kunci: pengetahuan, pernikahan usia dini, faktor, orang tua

\section{PENDAHULUAN}

Menurut Undang-Undang Nomor 1 tahun 1974 pada pasal 1 disebutkan bahwa pernikahan merupakan ikatan secara lahir batin antara laki-laki dan perempuan sebagai suami dan istri dengan tujuan membentuk keluarga atau rumah tangga bahagia dan kekal berdasarkan Tuhan Yang Maha Esa.
Pernikahan dikatakan sah, apabila dilakukan berdasarkan hukum yang dipercaya oleh masing-masing agama. Seseorang yang akan melakukan suatu pernikahan apabila belum mencapai usia 21 tahun harus mendapatkan izin terlebih dahulu dari kedua orang tua. Pernikahan dapat dilakukan dan diijinkan apabila laki-laki yang akan menikah telah 
mencapai usia 19 tahun dan pada perempuan mencapai usia 16 tahun.

United Nations Children's Fund (UNICEF) berpendapat pernikahan usia dini adalah pernikahan yang dilaksanakan secara resmi atau tidak resmi yang dilakukan sebelum usia 18 tahun (UNICEF, 2014). Sedangkan Badan Kependudukan dan Keluarga Berencana (BKKBN) berpendapat pernikahan yang sehat adalah pernikahan yang dilakukan oleh laki-laki yang telah memiliki usia 25 tahun dan pada perempuan telah memiliki usia 20 tahun. Hal ini dipertimbangkan atas dasar kesiapan dan pentingnya sistem reproduksi dalam pernikahan (BKKBN, 2010). Jadi pernikahan usia dini yang banyak dilakukan oleh masyarakat Indonesia yaitu pada perempuan usia 16 sampai 20 tahun.

Berdasarkan data United Nations Development Economic and Social Affairs (UNDESA), disebutkan bahwa Indonesia merupakan salah satu negara dengan kejadian pernikahan dini yang tergolong tinggi yaitu sebesar 34\%. Indonesia menempati urutan ke 37 dari 158 negara di dunia tentang pernikahan usia dini, sedangkan pada urutan Association of South East Asia Nations (ASEAN), Indonesia menempati urutan ke dua setelah negara Kamboja (UNDESA, 2011).

Menurut Riskesdas 2010, menunjukkan bahwa persentase perempuan usia 10 sampai 59 tahun, didapatkan 4,8\% dilakukan oleh anak usia 10 sampai 14 tahun sedangkan persentase terbesar dilakukan oleh usia 15 sampai 19 tahun sebesar 41,9\%. Pernikahan dengan jumlah paling rendah dilakukan oleh usia 35 tahun ke atas dengan persentase $0,6 \%$. Hal ini dapat dilihat dari Gambar 1. tentang persentase perempuan menikah pada usia 10 sampai 59 tahun berdasarkan Riskesdas 2010.

Survei Demografi dan Kesehatan Indonesia (SDKI) menyebutkan bahwa kasus pernikahan usia dini di Indonesia telah mencapai 50 juta penduduk. Provinsi di Indonesia yang memiliki persentase

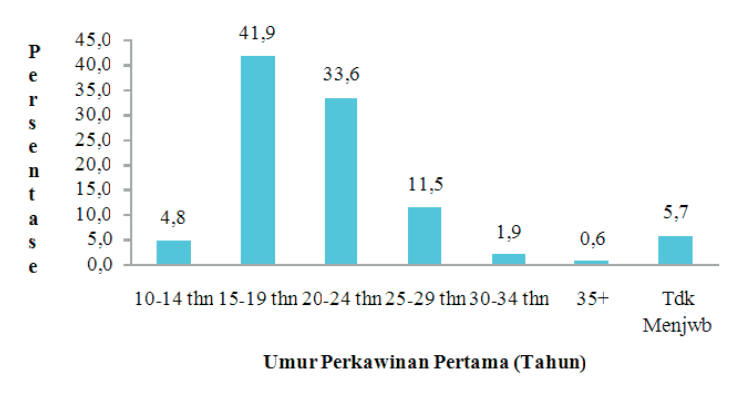

Sumber: Riskesdas 2010

Gambar 1. Persentase Perempuan Usia 10-59 Tahun menurut Usia Menikah Pertama di Indonesia Tahun 2010.

perempuan menikah usia dini yang tergolong tinggi yaitu Jawa Timur sebesar 39,43\%, Kalimantan Selatan sebesar 35,48\%, Jambi sebesar 30,63\%, dan Jawa Barat sebesar $36 \%$. (SDKI, 2007).

Hal tersebut juga di dukung dengan Hasil Laporan Analisis Data Perkawinan Usia Anak di Indonesia pada tahun 2016 yang menyebutkan bahwa Provinsi Jawa Timur merupakan Provinsi dengan jumlah remaja yang pernah menikah yaitu sebesar 236.404 jiwa. Kabupaten atau kota yang memiliki prevalensi tertinggi antara lain Kabupaten Bondowoso, Kabupaten Probolinggo, dan Kabupaten Situbondo. Kabupaten Bondowoso menempati urutan pertama di Provinsi Jawa Timur tentang pernikahan usia dini dengan jumlah persentase sebesar $35 \%$. Data ini di dukung dengan Laporan Data Teknis KUA Kecamatan Wonosari, Kabupaten Bondowoso tahun 2015, terdapat 271 pernikahan yang telah terdaftar pada bulan Januari-Desember. Pernikahan terbanyak terjadi pada usia 10 sampai 19 tahun.

Pernikahan usia dini masih banyak terjadi di berbagai daerah di Indonesia. Banyak faktor yang dapat menyebabkan terjadinya pernikahan usia dini, antara lain pendidikan, lingkungan, media masa, ekonomi, budaya setempat, serta pengetahuan. Berdasarkan penelitian Nurhayati tahun 2015 pengetahuan memiliki kontribusi yang kuat 
dalam pengambilan sikap atau keputusan yang akan diambil oleh seseorang. Semakin baik atau tinggi pengetahuan seseorang maka sikap terhadap pernikahan usia dini dapat di cegah atau semakin kecil.

Pengetahuan menurut Kamus Besar Bahasa Indonesia (KBBI) adalah segala sesuatu yang diketahui, dimana hal ini berhubungan dengan kepandaian seseorang. Pengetahuan adalah hasil dari pengindraan manusia, atau hasil pengamatan terhadap objek melalui indera yang dimiliki, seperti mata, hidung, telinga dan lainnya (Notoatmodjo, 2010). Serupa dengan pengertian yang disampaikan oleh Notoatmodjo, Mubarak (2011) berpendapat bahwa pengetahuan adalah segala sesuatu yang diketahui berdasarkan pengalaman yang didapatkan oleh setiap manusia.

Faktor yang memengaruhi pengetahuan adalah pendidikan, lingkungan, sosial budaya dan ekonomi, media masa, serta adanya pengalaman. Faktor yang memengaruhi pengetahuan juga merupakan faktor yang banyak terjadi pada pernikahan usia dini. Pernikahan usia dini memiliki dampak yang dapat ditimbulkan pada kesehatan, baik pada dampak fisik, mental, psikologi dan sosial.

Menurut Alfiyah (2010), disebutkan bahwa kecenderungan pernikahan usia dini yang akan terjadi, dipengaruhi oleh tingkat pendidikan dan pengetahuan yang rendah yang dimiliki oleh seseorang yang melakukan pernikahan usia dini. Hal ini sejalan dengan penelitian yang dilakukan oleh Nandang, et al (2009) yang menyebutkan bahwa perempuan yang memiliki pengetahuan rendah lebih memiliki risiko tinggi untuk melakukan pernikahan usia dini daripada perempuan yang memiliki pengetahuan tinggi.

Pengetahuan yang dimiliki oleh perempuan yang melakukan pernikahan usia dini juga berhubungan dengan pengetahuan yang dimiliki oleh orang tua. Pada pernikahan usia dini orang tua sangat memiliki peranan yang besar terhadap kejadian pernikahan usia dini. Hal ini sejalan dengan penelitian yang dilakukan oleh Juspin (2012), menyebutkan bahwa peran orang tua terhadap pernikahan usia dini sangat besar dalam membuat suatu keputusan. Hal ini juga tidak terlepas dari pengetahuan yang dimiliki orang tua itu sendiri.

Fenomena pernikahan usia dini masih banyak terjadi di Kecamatan Wonosari khususnya pada daerah pedesaan, sehingga tujuan dari penelitian ini untuk menganalisis adanya pengaruh pengetahuan yang dimiliki perempuan melakukan pernikahan usia dini di Kecamatan Wonosari Kabupaten Bondowoso.

\section{METODE PENELITIAN}

Penelitian ini merupakan penelitian deskriptif dengan menggunakan pendekatan kualitatif. Pengambilan sampel pada penelitian ini menggunakan purposive sampling untuk menentukan subjek yang akan diteliti. Cara penentuan informan dalam penelitian ini menggunakan data dari KUA Kecamatan Wonosari serta informasi yang diperoleh dari kepala desa setempat sebagai sumber informasi pendukung. Peneliti menggunakan data yang didapat sebagai acuan untuk melihat jumlah angka kejadian pernikahan usia dini pada setiap desa atau kelurahan. Pada Kecamatan Wonosari terdapat 12 desa atau kelurahan yang tersebar, peneliti mengambil 5 desa atau kelurahan yang ingin diteliti secara random, setelah terpilih 5 desa atau kelurahan. Peneliti mendatangi Kepala Desa pada setiap desa atau kelurahan terlebih dahulu untuk memastikan di desa atau kelurahan tersebut terdapat perempuan yang memiliki riwayat melakukan pernikahan usia dini. Pada penelitian ini terdapat dua kelompok informan yaitu informan kunci dan informan pendukung. Informan kunci merupakan perempuan yang memiliki riwayat melakukan pernikahan usia dini. Informan pendukung adalah orang tua, kepala desa atau kelurahan pada daerah tersebut.

Peneliti mencari informasi sebanyak mungkin pada semua informan, baik informan pendukung dan informan kunci terkait dengan pengetahuan tentang 
pernikahan usia dini yang mereka miliki. Informan kunci yaitu perempuan yang ingin di wawancara harus sesuai degan kriteria inklusi yang ditentukan.

Kriteria inklusi yang ditetapkan untuk menentukan informan yaitu bersedia di wawancara, usia menikah pertama di bawah 18 tahun, mampu memberikan informasi yang dibutuhkan, dan informan bertempat tinggal di Kecamatan Wonosari Kabupaten Bondowoso. Jumlah informan yang digunakan sebanyak 5 orang perempuan sebagai informan kunci yang melakukan pernikahan usia dini. Informan pendukung sebanyak 5 orang tua perempuan yang melakukan pernikahan usia dini, Camat Wonosari, Kepala Kua Kecamatan Wonosari dan 3 kepala desa.

Pengumpulan data diperoleh secara langsung dengan menggunakan indepth interview atau wawancara secara mendalam yang dilakukan kepada informan. Teknik analisis data yang peneliti yaitu penarikan kesimpulan terhadap data-data yang telah diperoleh di lapangan baik pada pengolahan data primer dan sekunder.

\section{HASIL}

\section{Karakteristik Subjek Penelitian}

Data hasil penelitian diketahui jumlah usia pertama menikah dan pendidikan terakhir yang ditempuh oleh informan kunci di Kecamatan Wonosari Kabupaten Bondowoso dengan total informan sebanyak 5 orang didapatkan.

Informan dipilih berdasarkan usia menikah pertama sebelum 18 tahun yang dilaksanakan di Kecamatan Wonosari Kabupaten Bondowoso. Tabel 1 menunjukkan bahwa informan yang diwawancarai secara mendalam berjumlah 5 orang dengan rentang usia 14 sampai 17 tahun. Usia informan saat ini di mulai dari usia 15 sampai 30 tahun. Pendidikan terakhir informan yaitu tamatan SD dan SMP.

Berdasarkan wawancara mendalam dengan informan yang melakukan pernikahan di bawah usia 18 tahun, alasan informan
Tabel 1. Karakteristik Informan Kunci

\begin{tabular}{cccc}
\hline $\begin{array}{c}\text { Kategori } \\
\text { Informan }\end{array}$ & $\begin{array}{c}\text { Usia } \\
\text { pertama } \\
\text { menikah }\end{array}$ & $\begin{array}{c}\text { Usia } \\
\text { saat ini }\end{array}$ & $\begin{array}{c}\text { Pendidikan } \\
\text { Terakhir }\end{array}$ \\
\hline Informan 1 & 15 tahun & 24 tahun & SMP \\
Informan 2 & 14 tahun & 30 tahun & SD \\
Informan 3 & 17 tahun & 19 tahun & SMP \\
Informan 4 & 17 tahun & 17 tahun & SMP \\
Informan 5 & 15 tahun & 15 tahun & SD \\
\hline
\end{tabular}

tidak melanjutkan pendidikan ke tingkat yang lebih tinggi dikarenakan beberapa hal, yaitu informan pernah melanjutkan sekolah di madrasah setelah lulus SD yang setara dengan SMP, (informan 2). Informan tidak melanjutkan hingga tamat SMP dikarenakan orang tua yang memintanya untuk menikah. Pengakuan informan dikutip dalam percakapan sebagai berikut:

"Dulu saya sekolah di madrasah dek, yang setara dengan SMP, tapi waktu saya kenaikan kelas 2, orang tua meminta saya untuk pulang ke rumah dan berhenti. Karena saya disuruh menikah dengan orang tua" (Informan 2, 30 tahun)

Hal ini sejalan dengan yang dialami oleh informan 4. Informan 4 awalnya pernah bersekolah SMA namun tidak melanjutkan sampai lulus. Pengakuan informan 4 dikutip dalam percakapan sebagai berikut:

"Saya sekolah kelas 2 SMA terus berhenti mbak, karena sudah ga terlalu niat juga untuk sekolah. Orang tua menyuruh saya menikah karena sudah sering keluar dengan pasangan saya. Saya juga setuju dengan pendapat orang tua mbak untuk menikah,..." (Informan 4, 17 tahun).

Berdasarkan beberapa pernyataan informan, dapat disimpulkan perempuan yang melakukan pernikahan usia dini tidak memiliki kekuatan untuk menolak keinginan sikap orang tua untuk menikahkan anaknya 
daripada sekolah. Selain diri sendiri seharusnya orang tua memiliki peran dan dukungan yang besar untuk menyekolahkan anaknya agar mendapat pendidikan yang layak dan baik di masa depan.

Berdasarkan Tabel 2. diketahui bahwa terdapat 5 orang tua dari informan kunci yang diwawancarai secara mendalam. Kelima orang tua tersebut memiliki pendidikan terakhir tamatan SD dan SMP. Terdapat 1 orang tua yaitu orang tua informan 2 yang tidak memiliki riwayat pendidikan sekolah normal, berdasarkan informasi, orang tua pernah bersekolah namun berhenti dan tidak sampai lulus.

Tabel 2. Karakteristik Orang Tua Informan Kunci

\begin{tabular}{ccc}
\hline Kategori Informan & $\begin{array}{c}\text { Usia saat } \\
\text { ini }\end{array}$ & $\begin{array}{c}\text { Pendidikan } \\
\text { Terakhir }\end{array}$ \\
\hline Orang tua informan 1 & 71 tahun & SMP \\
Orang tua informan 2 & 85 tahun & - \\
Orang tua informan 3 & 44 tahun & SMP \\
Orang tua informan 4 & 39 tahun & SD \\
Orang tua informan 5 & - tahun & SD \\
\hline
\end{tabular}

Berikut pernyataan yang diungkapkan oleh orang tua informan 2 sebagai berikut :

"Zaman dulu sekolah mahan nduk, pernah sekolah SD tapi kelas 3 berhenti, bantu orang tua di rumah" (Orang tua Informan 2, 85 tahun)

Berbeda dengan orang tua informan 5 yang tidak mengetahui pasti usia saat ini. Orang tua informan 5 mengaku bahwa memang tidak tahu sejak kecil tahun kelahirannya secara pasti. Berikut kutipan pernyataan orang tua informan 5 :

"Saya tidak tahu nduk berapa umur saya sekarang, di KTP umur hanya dikira-kira, zaman dulu orang tua kan tidak mengerti hal seperti ini, jadi dari dulu orang tua saya memang tidak memberi tahu secara jelas saya lahir di tahun berapa. Kalau nduk tanya saya umur berapa sekarang, nduk kira-kira saja ya saya umur berapa" (Orang tua Informan 5)

Orang tua dari informan 5 juga berpendapat tidak melanjutkan sekolah, karena pada zaman dulu orang tua menyuruhnya menikah dengan alasan sudah dianggap dewasa. Berikut kutipan pernyataan orang tua informan 5 :

"Kalau zaman dulu kan memang jarang yang sekolah nduk, saya dulu berhenti sekolah ya karena orang tua tidak punya biaya untuk menyekolahkan jadinya saya tidak melanjutkan sekolah, tempatnya juga jauh nduk sekolah disini, nduk tau sendiri jalan menuju ke sini saja susah dan jauh" (Orang tua Informan 5)

Pernyataan di atas merupakan beberapa pendapat orang tua terkait karakteristik usia dan pendidikan yang mereka miliki. Menurut mereka pada zaman dahulu untuk mendapat pendidikan tinggi sangatlah susah, didukung dengan faktor ekonomi dan orang tua serta letak sekolah yang jauh di daerah pedesaan.

\section{Kontribusi Pengetahuan terhadap sikap pernikahan usia dini}

Pengetahuan seseorang erat kaitannya dengan pendidikan yang dimiliki orang tersebut. Informan perempuan maupun orang tua yang melakukan pernikahan usia dini, mayoritas memiliki pendidikan SMP. Pengetahuan informan tentang peraturan pernikahan usia dini baik pengertian berdasarkan Undang-Undang, serta batasan umur, semua menjawab tidak tahu tentang adanya Undang-Undang yang mengatur pernikahan usia dini. Keseluruhan informan juga masih banyak yang tidak mengerti batasan umur saat diperbolehkan menikah, baik pada laki-laki maupun perempuan.

Berdasarkan hasil wawancara mendalam dengan informan 1 beserta orang tuanya, jawaban dari informan 1 
hanya mengira-ngira batasan umur yang baik untuk menikah tanpa menyebutkan secara rinci umur yang baik untuk laki-laki ataupun perempuan. Jawaban dari orang tua informan 1 ketika ditanya tentang batasan usia menikah pertama, orang tua informan menjawab dengan rincian umur yang baik dan diperbolehkan menikah bagi lakilaki maupun perempuan. Berikut kutipan percakapan informan 1 dan orang tua informan 1 ketika ditanya tentang batasan umur menikah menurut Undang-Undang yang didapat ketika melakukan wawancara mendalam :

"Kalau umur yang baik saya kurang tahu dek, waktu itu saya masih 15 tahun, itu ga diizinkan menikah, ya mungkin sekitar segitu ya dek" (Informan 1, 24 tahun)

"Tahu ndok, kalau cewek umur 17 tahun, kalau cowok umur 20 tahun." (Orang tua Informan 1, 71 tahun)

Jawaban di atas menggambarkan bahwa pengetahuan perempuan yang melakukan pernikahan usia dini terhadap pengetahuan terkait batasan usia menikah pertama jelas dapat tergambarkan bahwa perempuan tersebut kurang mengetahui hal tersebut. Sedangkan pada orang tua informan 1 pengetahuan tentang batasan usia dapat tergolong baik walaupun jawabannya masih kurang tepat apabila dibandingkan dengan batasan usia menikah pertama yang ada pada Undang-Undang.

Pengetahuan dalam penelitian ini juga berpengaruh terhadap lingkungan di sekitar. Rendahnya pengetahuan di lingkungan masyarakat Kecamatan Wonosari terhadap pernikahan usia dini menyebabkan fenomena ataupun perilaku menikah usia dini yang dilakukan di daerah pedesaan tidak menjadi suatu permasalahan. Informan kunci berpendapat bahwa lingkungan pada tempat tinggal mereka terhadap pernikahan usia dini. Semua informan menjawab bahwa tidak ada masalah dengan pernikahan yang dilakukan oleh perempuan yang menikah di bawah usia 18 tahun.

Akses ke daerah pedesaan juga membuat perempuan menjadi kurang update terhadap informasi ataupun berita yang sedang banyak dibahas di Indonesia maupun dunia. Pada informan kunci, hanya terdapat 2 informan yang memiliki telepon seluler, namun telepon seluler yang dimiliki tidak dapat terhubung dengan internet. Sedangkan orang tua dari informan semuanya mengaku tidak memiliki telepon seluler. Media elektronik seperti televisi telah tersedia di rumah masing-masing, namun tontonan yang paling diminati oleh masyarakat pedesaan di daerah Kecamatan Wonosari bukanlah berita, namun tayangan sinetron.

Pengalaman dari orang di sekitar atau lingkungan tentang pernikahan usia dini yang menyebutkan bahwa dari 5 informan kunci, 2 menjawab melakukan pernikahan usia dini karena alasan pengalaman yang didapat dari orang tua dan keluarga. Pada informan kunci yang lain menjawab bahwa karena adanya rasa cinta terhadap calon suami, dan 1 informan menjawab karena adanya paksaan dari orang tua sehingga ia mau melakukan pernikahan di usia dini walaupun hal tersebut tidak sesuai dengan kemauannya. Pengalaman yang dirasakan oleh orang tua memiliki peranan besar sehingga membuat orang tua berani memilih sikap menikahkan anaknya pada usia yang masih sangat dini.

Dampak yang dirasakan setelah perempuan melakukan pernikahan usia dini antara lain adalah adanya sikap tertekan yang dirasakan oleh perempuan setelah menikah, terdapat pemikiran-pemikiran yang memaksakan perempuan yang melakukan pernikahan usia dini menjadi lebih dewasa sebelum waktunya, emosi yang masih tidak stabil, komunikasi dengan lingkungan yang terbatas, serta pada masalah kesehatan yang dirasakan yaitu terdapat 3 informan yang telah memiliki anak, berdasarkan hasil wawancara didapatkan masalah normal yang sering dialami pada ibu hamil seperti 
bengkaknya kaki pada saat kehamilan, rasa mual yang sering muncul, serta mudah lelah. Pengetahuan rendah yang dimiliki oleh informan tidak menjadikan informan menutup telinga akan program yang diadakan oleh pemerintah.

\section{PEMBAHASAN}

\section{Karakteristik Informan}

Pada penelitian ini informan yang melakukan pernikahan usia dini masih tergolong sangat muda, karena melakukan pernikahan pertama pada usia 14 sampai 17 tahun. Informan juga memiliki pendidikan yang dapat digolongkan pendidikan yang tidak mengikuti program pemerintah yaitu wajib belajar 9 tahun. Hal ini dibuktikan dengan pendidikan terakhir informan adalah SD dan SMP, terdapat informan yang pernah melanjutkan SMP namun berhenti atau putus di tengah jalan yang diakibatkan karena melakukan pernikahan usia dini sehingga mereka tidak dapat melanjutkan sekolah.

Karakteristik pada informan juga tidak jauh beda dengan karakteristik informan kunci, dengan riwayat pernikahan juga melakukan pernikahan usia dini. Pendidikan yang ditempuh oleh orang tua dari informan kunci juga SD dan SMP bahkan terdapat datu orang tua yaitu orang tua informan 2 yang tidak melanjutkan sekolah pada tingkat SD sehingga tidak ada pendidikan terakhir yang ditempuh.

\section{Kontribusi Pendidikan terhadap Pengetahuan}

Pernikahan usia dini bagi individu yang ingin melakukannya haruslah memiliki kesiapan baik secara fisik, psikologi, mental dan sosial. Selain itu individu juga harus memiliki kesiapan secara emosi dalam menyikapi setiap tanggapan masyarakat baik itu negatif maupun positif. Kesiapan dalam menghadapi setiap permasalahan yang akan ada dan timbul pada saat berumah tangga dari permasalahan kecil sampai dengan permasalahan yang besar. Pernikahan usia dini bagi individu yang melakukannya harus memiliki pemikiran yang matang dalam membuat dan menentukan suatu keputusan dalam menghadapi dan memecahkan suatu permasalahan.

Dalam menentukan suatu keputusan yang akan diambil baik atau buruk, individu seharusnya memiliki pengetahuan yang berhubungan dengan pendidikan individu itu sendiri. Pendidikan yang dimiliki oleh perempuan yang melakukan pernikahan usia dini di Kecamatan Wonosari Kabupaten Bondowoso tergolong rendah. Pada 5 informan yang melakukan pernikahan usia dini, tidak ada satu pun yang melanjutkan sekolah ke jenjang yang lebih tinggi. Berdasarkan hasil wawancara dengan informan terdapat 3 informan yang pernah melanjutkan sekolah ke jenjang yang lebih tinggi namun perempuan tersebut lebih memilih untuk berhenti dan tidak melanjutkan sampai selesai atau lulus.

Berdasarkan keterangan informan, alasan informan tidak melanjutkan pendidikannya atau sekolah dikarenakan adanya paksaan, maupun desakan orang tua untuk segera menikah. Kemudian alasan ekonomi juga menjadikan informan untuk tidak melanjutkan sekolah dan lebih memilih untuk menikah. Kemauan dari diri sendiri yang rendah untuk sekolah juga menjadikan alasan untuk perempuan mau segera dinikahkan.

Pengetahuan yang dimiliki dapat berpengaruh terhadap rendahnya pendidikan yang juga dimiliki oleh perempuan dan orang tua yang melakukan pernikahan usia dini. Perempuan yang melakukan pernikahan usia dini cenderung memiliki status pendidikan yang rendah, baik dalam keluarga maupun lingkungan tempat tinggalnya. Hal ini berpengaruh terhadap kejadian pernikahan usia dini yang dilakukan oleh perempuan di Kecamatan Wonosari. Hal ini sejalan dengan penelitian yang dilakukan oleh Sriharyati yang menyatakan bahwa Rendahnya tingkat pendidikan maupun pengetahuan anak, orang tua dan masyarakat, menyebabkan adanya kecenderungan menikahkan anak 
perempuannya yang masih di bawah umur (Sriharyati, 2012). Penelitian ini juga sejalan dengan yang dilakukan Stang yang berpendapat bahwa semakin rendah pendidikan seseorang kecenderungan untuk melakukan pernikahan usia dini semakin tinggi (Stang, 2011).

Hal ini juga sejalan dengan Theory of Planned Behavioural (TPB) yang menyebutkan pendidikan memiliki pengaruh terhadap pengambilan atau penentuan sikap, norma subjektif serta kontrol perilaku dari individu maupun orang tua yang melakukan pernikahan usia dini (Ajzen, 2005).

\section{Kontribusi Lingkungan terhadap Pengetahuan}

Pernikahan usia dini banyak dilakukan oleh perempuan yang bertempat tinggal di daerah pedesaan. Hal ini juga berhubungan dengan adanya pengetahuan yang ada pada lingkungan tentang pernikahan usia dini. Berdasarkan hasil yang didapat pada wawancara bersama informan, respons lingkungan di Kecamatan Wonosari terhadap pernikahan usia dini yaitu tidak menjadikan fenomena pernikahan usia dini sebagai hal yang dilarang.

Perilaku menikah di usia dini telah menjadi kebudayaan yang sudah ada sejak dahulu dan turun-temurun. Pengetahuan yang rendah juga menjadikan masyarakat terus-menerus mengikuti kebudayaan yang ada. Pengaruh dari lingkungan dilakukan tanpa melihat dampak yang akan dirasakan oleh perempuan yang melakukan pernikahan usia dini baik pada lingkungan itu sendiri maupun kesehatan.

Sejalan dengan penelitian yang dilakukan oleh Khaparistia \& Edward yang menyatakan bahwa rendahnya pengetahuan menyebabkan lingkungan mendukung terjadinya pernikahan usia dini. Pengalaman dan kebiasaan yang sudah berjalan turuntemurun membuat remaja cenderung ingin mengikuti perilaku menikah dini. Remaja yang berada di lingkungan yang banyak melakukan pernikahan usia dini dapat mudah terpengaruh dengan sikap atau kecenderungan yang ada di lingkungannya (Khaparistia \& Edward, 2015).

Hal ini juga sejalan dengan TPB yang menyatakan lingkungan sosial di sekitar yang berkaitan langsung dengan kehidupan seorang individu dapat memberikan pengaruh dalam pengambilan keputusan pada individu, dalam hal ini yaitu pernikahan usia dini (Ajzen, 2005).

\section{Kontribusi Media Masa terhadap Pengetahuan}

Pengetahuan tentang pernikahan usia dini juga dapat diperoleh dari media masa yang mudah dijumpai pada saat ini. Media masa merupakan salah satu hal yang menjadikan masyarakat kurang mendapat pengetahuan tentang pernikahan usia dini. Media elektronik yang paling banyak digunakan untuk mendapatkan informasi satu-satunya di masyarakat di Kecamatan Wonosari adalah televisi. Namun televisi yang seharusnya digunakan untuk mendapatkan informasi menjadi kurang berpengaruh karena terbatasnya saluran televisi yang dimiliki oleh informan. Letak rumah informan yang rata-rata berada di daerah pedesaan menjadi salah satu hal yang berpengaruh dalam pengetahuan terhadap media masa.

Kurangnya minat masyarakat untuk menonton atau mendengarkan berita di televisi membuat informasi yang mereka dapat menjadi kurang. Masyarakat memanfaatkan televisi sebagai sarana hiburan setelah pekerjaan ataupun kesibukan selesai dilakukan. Saluran televisi yang paling banyak ditonton oleh masyarakat adalah sinetron.

Alat komunikasi telepon seluler merupakan alat yang paling mudah digunakan dan dimiliki oleh banyak orang. Kenyataannya informan banyak yang tidak memiliki telepon seluler. Hal ini dikarenakan pekerjaan yang dimiliki oleh informan sebagai ibu rumah tangga serta pekerjaan suami yang di dominasi oleh petani membuat 
perekonomian informan tergolong rendah. Telepon seluler yang dimiliki informan tidak dapat terhubung dengan internet, sehingga untuk mendapatkan informasi tentang pernikahan usia dini informan sulit untuk mendapatkannya.

Hal ini juga menyebabkan salah satu pengetahuan yang dimiliki oleh informan menjadi terbatas bahkan rendah. Apabila pengetahuan yang dimiliki rendah maka perilaku pernikahan usia dini juga akan masih ada di daerah pedesaan khususnya di Kecamatan Wonosari.

Menurut Naibaho (2014) menyebutkan pada masa modern ini media sangat mudah untuk dijumpai baik media cetak, elektronik dan lainnya. Media cetak maupun elektronik adalah media yang paling banyak digunakan oleh masyarakat di daerah pedesaan maupun perkotaan. Media massa sering digunakan sebagai alat penyampaian pesan atau informasi dua arah, baik dari media massa kepada masyarakat, ataupun masyarakat dengan masyarakat itu sendiri. Namun hal ini berbeda dengan penelitian yang dilakukan di Kecamatan Wonosari, di daerah tersebut walaupun zaman sudah semakin maju tidak menjadikan masyarakat mengikuti kemajuan teknologi, hal ini dibuktikan dengan banyaknya informan yang belum memiliki telepon seluler.

Penelitian ini sejalan dengan TPB yang menyebutkan bahwa media masa juga memiliki pengaruh terhadap pengetahuan atau informasi yang akan didapatkan. Hal ini berhubungan dengan pengambilan atau penentuan sikap, norma subjektif serta kontrol perilaku dari individu maupun orang tua terhadap perilaku pernikahan usia dini (Ajzen, 2005).

\section{Kontribusi Pengalaman atau riwayat terhadap Pengetahuan}

Pengetahuan dalam pernikahan usia dini pada perempuan juga didapat dari adanya pengalaman baik pada riwayat orang tua, keluarga maupun lingkungan yang pernah melakukan pernikahan usia dini. Pada penelitian ini informan kunci yakin bahwa pengalaman yang didapat dari melihat dan mendengarkan cerita dari orang tua, keluarga yang juga melakukan pernikahan usia dini memiliki dampak yang baik terhadap masa depan mereka ketika mereka memilih untuk melakukan pernikahan usia dini.

Berdasarkan hasil wawancara mendalam dari lima informan kunci terdapat dua informan yang mengaku melakukan pernikahan usia dini karena melihat pengalaman dari teman dan keluarga yang telah melakukan pernikahan usia dini. Informan berpendapat bahwa setelah menikah, teman maupun keluarganya menjadi lebih bahagia dan tentram dalam menjalani kehidupan. Hal ini menjadikan informan mau untuk segera menikah oleh orang tua.

Berbeda dengan dua informan lain yang berpendapat bahwa pernikahan usia dini dilakukan berdasarkan atas kemauan orang tua. Pengalaman yang dialami orang tua tentang pernikahan usia dini membuat dua informan ini diarahkan oleh orang tua untuk segera menikah. Ada satu informan yang berpendapat bahwa tidak semua pengalaman yang didapatkan mendapatkan hal yang baik. Ada pula pengalaman maupun cerita buruk yang didapatkan. Informan 2, berpendapat bahwa pengalaman tentang pernikahan usia dini baik pada orang tua, keluarga, maupun lingkungan disekitarnya tidak membuat informan ini memiliki pemikiran yang sama tentang pernikahan usia dini. Ia berpendapat bahwa pernikahan usia dini merupakan suatu penyesalan, hal ini dikarenakan setelah menikah kehidupan yang didapat tidak seindah cerita ataupun apa yang ia lihat pada orang lain.

Penelitian ini sejalan dengan TPB, bahwa pengalaman atau riwayat dari orang di sekitar atau lingkungan pada informan kunci dapat memengaruhi informan dalam menentukan perilaku yang akan diambil oleh individu tersebut (Ajzen, 2005). 


\section{Kontribusi Pengetahuan terhadap Kesehatan}

Dampak bagi kesehatan yang dapat dirasakan pada perempuan yang melakukan pernikahan usia dini yang dilakukan di Kecamatan Wonosari Kabupaten Bondowoso. Berdasarkan lima informan yang diwawancarai oleh peneliti terdapat tiga informan telah memiliki anak dan dua informan belum memiliki anak. Hal ini dikarenakan terdapat informan yang memilih untuk menunda memiliki anak dengan alasan tahu dampak yang akan dirasakan bagi kesehatannya serta adanya nasihat dari orang tua untuk menunda memiliki anak sebelum berusia 20 tahun. Dampak Kesehatan yang dimaksud adalah sebagai berikut :

Dampak Kesehatan secara fisik yang dirasakan yaitu dewasa sebelum waktunya. Adanya tanggung jawab dan kewajiban menjadi seorang istri membuat informan yang menikah pada usia 14 sampai 17 tahun tidak dapat menolak kemauan suami untuk berhubungan seksual. Hal ini dirasakan oleh salah satu informan yang harus mengurus suami dan belajar memasak. Pada umur yang masih muda, yaitu 14 tahun seharusnya anak masih dapat bermain dan belajar bersama teman-temannya.

Berdasarkan penelitian yang dilakukan Kusmiran (2011) dampak fisik dari pernikahan usia dini bagi kesehatan perempuan yaitu adanya kanker mulut rahim, perempuan yang hamil pertama kali kurang dari 17 tahun memiliki kemungkinan 2 kali lipat lebih besar untuk terkena kanker serviks di usia tuanya dari pada perempuan yang menunda kehamilannya hingga usia 25 tahun atau lebih tua. Kejadian kanker serviks lebih tinggi terjadi pada perempuan yang menikah daripada yang tidak menikah terutama pada gadis yang koitus pertama (coitarche) dialami pada usia amat muda kurang dari 16 tahun.

Dampak Biologis yang dirasakan oleh informan kunci yaitu pada informan yang memiliki anak di usia masih muda, ketika melahirkan seorang anak, informan tidak dapat memberikan Air Susu Ibu (ASI) dikarenakan tidak terdapat ASI yang dapat diproduksi. Berdasarkan hasil wawancara dengan informan dampak biologis yang dirasakan pada informan yang sudah memiliki anak yaitu gejala-gejala normal yang biasa atau sering dirasakan oleh ibu hamil pada umumnya seperti kaki bengkak pada saat kehamilan, tidak memilki nafsu makan, mudah mual dan lainnya.

Dampak biologis ini juga tidak hanya dirasakan oleh informan kunci namun anak yang dilahirkannya juga dapat merasakan dampaknya. Berdasarkan hasil dari wawancara yang dilakukan oleh peneliti terdapat anak dari salah satu informan yang mengalami gangguan pada anggota badannya yaitu tidak dapat berbicara karena anak tersebut tidak dapat mendengar, dengan umur yang sudah 6 tahun hal ini membuat informan menjadi khawatir. Berdasarkan keterangan dari informan, menurut tenaga medis terdapat gangguan pada sistem pendengarannya, sehingga membutuhkan alat untuk membantu anak tersebut mendengar dan berbicara.

Dampak biologis yang berbeda dialami oleh anak dari salah satu informan yang lain. Berdasarkan keterangan yang dijelaskan oleh informan, anaknya mengalami keterlambatan untuk berpikir dan berkomunikasi dengan orang, daya tangkap yang dimiliki oleh anaknya sangatlah lama, sehingga dalam berkomunikasi sedikit lama.

Dampak psikologi yaitu mudah terjadi perceraian dan pertengkaran pada rumah tangga, hal ini di akui oleh lima informan kunci pada saat awal pernikahan sering terjadi pertengkaran yang membawa dampak baik dan buruk. Dampak baik yang dirasakan yaitu dari adanya perselisihan semakin membuat informan dan suami semakin dewasa dalam menghadapi permasalahan, apabila bisa menghadapi masalah tersebut. Namun apabila informan dan suami tidak dapat menyelesaikan permasalahan tersebut hal ini menjadikan rumah tangga dapat berujung pada perceraian. 
Pengalaman yang sama juga dialami oleh informan 2, yaitu mengalami perceraian dalam rumah tangganya. Perceraian terjadi karena kurangnya sikap saling pengertian antara pasangan, sehingga membuat informan memilih untuk bercerai. Berbeda hal nya dengan informan 3 yang menjelaskan bahwa ketika ada pertengkaran, informan dan suami memiliki cara sendiri untuk menyelesaikannya, yaitu dengan cara keluar rumah dan menyelesaikan di luar rumah, agar orang tua dan keluarga tidak khawatir dengan pertengkaran yang mereka alami, informan 3 memiliki kesepakatan bahwa setiap permasalahan harus segera diselesaikan agar tidak berlarut-larut.

Berdasarkan penelitian yang dilakukan oleh Supriyati pada penelitiannya ia berpendapat bahwa tidak semua pernikahan usia dini berdampak pada terjadinya perceraian. Tujuan pernikahan untuk membentuk keluarga yang bahagia dan kekal berdasarkan Ketuhanan Yang Maha Esa (Supriyati, 2011).

Dampak Mental yang dirasakan yaitu lebih pendiam setelah menikah, karena merasa tertekan akibat keterpaksaan menikah di usia dini. Keterpaksaan dialami oleh informan 2 yang bertahan hingga usia pernikahan 6 tahun. Selama pernikahan informan merasa tertekan karena banyaknya aturan yang di berikan oleh mertua serta tidak adanya perlindungan dari suami membuat informan 2 merasa tertekan dalam pernikahannya.

Dampak mental berbeda dengan yang dirasakan informan 3, yang merasa tertekan karena sifat cemburu dan aturan suami yang melarang untuk keluar bersama teman-teman seusianya, sehingga informan 3 merasa kurang nyaman dan terbatas untuk berteman.

Dampak Sosial yang dapat dirasakan yaitu terbatasnya ruang lingkup yang dirasakan informan untuk bergaul dan berkomunikasi dengan lingkungannya menjadi berkurang, hal ini seperti yang dirasakan informan 3, yaitu terbatasnya komunikasi dengan teman dan lingkungan disekitarnya. Sehingga hal ini juga menjadikan hilangnya masa remaja yang dialami oleh informan 3.

Dampak Sosial terjadinya pernikahan usia dini yaitu keterbatasan ruang lingkup untuk bergaul dengan teman-teman seumuran, sehingga remaja kurang dapat membicarakan masalah yang dihadapinya (Erma, 2012).

Penjelasan informan terhadap dampak pernikahan usia dini yang dirasakan masih banyak yang kurang mengetahui baik pada orang tua dan masyarakat sehingga hal tersebut tanpa disadari dapat memberikan pengaruh pada perempuan yang menikah di usia dini.

\section{SIMPULAN}

Perempuan yang memiliki riwayat menikah pertama di Kecamatan Wonosari Kabupaten Bondowoso berusia di bawah 18 tahun. Pendidikan yang ditempuh baik pada informan kunci maupun informan pendukung adalah SD dan SMP.

Kontribusi yang berpengaruh dalam pernikahan usia dini pada penelitian ini yaitu rendahnya pengetahuan yang dimiliki oleh informan kunci dan informan pendukung. Hal ini berkaitan dengan riwayat pendidikan yang dimiliki oleh informan, rendahnya pengetahuan pada lingkungan terhadap pernikahan usia dini, rendahnya pemanfaatan media masa sebagai sarana mencari informasi, pengalaman pada orang tua, keluarga maupun lingkungan hal tersebut menjadikan perilaku pernikahan usia dini biasa dilakukan. Pengetahuan yang rendah yang dimiliki oleh informan terhadap dampak kesehatan yang akan dirasakan setelah menikah di usia dini menjadikan masyarakat terus-menerus melakukan kebiasaan menikah usia dini.

Saran yang dapat diberikan berdasarkan kesimpulan yang disampaikan oleh peneliti dalam penelitian ini yaitu : 


\section{Bagi Masyarakat}

Harus adanya kesadaran dari masyarakat atau lingkungan tentang peningkatan usia dini. Peningkatan wawasan dan informasi tentang pernikahan usia dini, dan pengaruh yang dapat dirasakan untuk kehidupan ke depannya.

\section{Bagi Tenaga Kesehatan}

Adanya peran aktif dari tenaga kesehatan untuk memberikan penyuluhan kepada remaja tentang pernikahan usia dini. Pada hal ini khususnya remaja perempuan tentang pentingnya pengetahuan pernikahan usia dini berdasarkan usia yang disarankan berdasarkan peraturan Undang-Undang dan usia yang baik bagi kesehatan reproduksi serta dampak yang dapat dirasakan apabila melakukan pernikahan usia dini.

\section{Bagi Remaja Perempuan}

Perempuan dapat terus menambah wawasan dan pengetahuan tentang pernikahan usia dini. Mengikuti kegiatan yang positif dan bermanfaat sebagai sarana pemahaman untuk diri sendiri. Memilih teman bergaul secara benar agar tidak terjerumus pada pengambilan keputusan yang salah untuk menikah usia dini.

\section{DAFTAR PUSTAKA}

Abdulah, Z.A., Thata, R., Landing, J. 2009. Studi kasus pernikahan dini pada masyarakat Kecamatan Sanggalangi Kabupaten Tana Toraja. Jurnal MKMI, 5(4).

Agtikasari, N. 2015. Hubungan Pengetahuan tentang Pernikahan Usia Dini dengan Sikap Siswa terhadap Pernikahan Usia Dini di SMA Negeri 2 Banguntapan Bantul Tahun 2015. STIKES'Aisyiyah Yogyakarta.

Aisyaroh, N., Kebidanan, S.P.P.D.I., Unissula, F.I.K. 2010. Kesehatan Reproduksi Remaja. Jurnal Majalah Ilmiah Sultan Agung.

Ajzen, I. 2005. Attitudes, personality, and behavior. McGraw-Hill Education (UK).
Arimurti, I. 2017. Analisis Penyebab Terjadinya Pernikahan Usia Dini Terhadap Kesehatan Masyarakat Di Kecamatan Wonosari Kabupaten Bondowoso. Skripsi. Universitas Airlangga.

BKKBN. 2010. Pendewasaan Usia Perkawinan dan Hak-hak Reproduksi bagi Remaja Indonesia. Jakarta: http:// cerita.bkkbn.go.id.

BPS, Bappenas. 2016, Laporan Analisis Data Perkawinan Usia Anak di Indonesia 2016, Jakarta: BPS, Bappenas.

Badan Penelitian Dan Pengembangan Kesehatan Kementerian Kesehatan RI. 2010. Riset Kesehatan Dasar (Riskesdas) 2010. Jakarta: Kementerian Kesehatan.

Desiyanti, I.W. 2015. Faktor-Faktor yang Berhubungan Terhadap Pernikahan Dini Pada Pasangan Usia Subur di Kecamatan Mapanget Kota Manado. JIKMU, 5(3).

Dwinanda, A.R., Wijayanti, A.C. Werdani, K.E. 2016. Hubungan Antara Pendidikan Ibu dan Pengetahuan Responden dengan Pernikahan Usia Dini. Jurnal Kesehatan Masyarakat Andalas, 10(1), pp.76-81.

Fatusi, A.O. 2016. Young People's Sexual and Reproductive Health Interventions in Developing Countries: Making the Investments Count. Journal of Adolescent Health, 59(3), S1-S3.

Follona, W., Raksanagara, A.S., Purwara, B. H. 2014. Perbedaan Pendidikan Kelompok Sebaya tentang Pendewasaan Usia Perkawinan di Perkotaan dan Perdesaan. Kesmas: National Public Health Journal, 9 (2), 157-163.

Hanum, Y. 2015. Dampak Pernikahan Dini Terhadap Kesehatan Alat Reproduksi Wanita. Jurnal Keluarga Sehat Sejahtera, 13(26).

Januar, V., \& Putri, D.E. 2011. Citra Tubuh Pada Remaja Putri Menikah Dan Memiliki Anak. Jurnal Ilmiah Psikologi, 1 (1).

Kantor Kementerian Agama, Kabupaten Bondowoso. 2015. Laporan Data Teknis KUA Kecamatan Wonosari. Bondowoso 
Khaparistia, E. and Edward, E. 2015. Faktor-Faktor Penyebab Terjadinya Pernikahan Usia Muda Studi Kasus di Kelurahan Sawit Seberang Kecamatan Sawit Seberang Kabupaten Langkat The Factors That Cause The Young Age Of Marriage In The Village Of Case Studies Across The Sawit Seberang Sub-Dis. Jurnal Pemberdayaan Komunitas, Vol. 14. No. 1.

Kusmiran, E. 2011. Kesehatan reproduksi remaja dan wanita. Jakarta: Salemba Medika.

Landung, J., et al . 2009. Studi Kasus Kebiasaan Pernikahan Usia Dini Pada Masyarakat Kecamatan Sanggalangi Kabupaten Tana Toraja. Jurnal MKMI, Vol. 5. No. 4.

Maleong, L.J, 2003. Metodologi Penelitian Kualitatif. Bandung: Remaja Rosdakarya, Hal. 3.

McNicoll, G. 2006. United Nations Department Of Economic and Social Affairs, Population Division: Population, Resources, Environment and Development Database, Version 4.0. Population and Development Review, 32(4), 790-791.

Mubarak, I, W., 2012. Promosi Kesehatan Untuk Kebidanan. Salemba Medika. Jakarta.

Naibaho, H., 2014. Faktor-Faktor yang Memengaruhi Pernikahan Usia Muda (Studi Kasus Di Dusun IX Seroja Pasar VII Tembung Kecamatan Percut Sei Tuan Kabupaten Deli Serdang). Welfare StatE, Vol. 2. No. 4.

Nandang M., Ijun R. 2007. Faktor-faktor yang berhubungan dengan Usia Menikah Muda pada Wanita Dewasa Muda di Kelurahan Mekarsari Kota Bandung.Jurnal Kesehatan Kartika STIKES A. Yani.

Notoatmodjo, S. 2010. Metode Ilmu Pengetahuan. Metodologi Penelitian Kesehatan. Jakarta: Rineka Cipta.

Pemerintah Republik Indonesia. 1974. Undang-Undang RI Nomor 1 tahun 1974 tentang Perkawinan. Jakarta: Pemerintah RI.
Puspitasari, R.D. and Waluyo, S.T.I.K.N. 2014. Gambaran Pengetahuan Ibu Remaja Putri tentang Dampak Pernikahan Usia Muda Pada Kesehatan Reproduksi di Desa Tegaldowo Kecamatan Gunem Kabupaten Rembang. Jurnal STIKES.

Roqib, M. 2010. Pernikahan Dini Dan Lambat: Merampas Hak-Hak Anak. Yin Yang, 5(2), pp. 298-311.

Soejoeti, S.Z. 2001. Perilaku seks di kalangan remaja dan permasalahannya. Media Penelitian dan Pengembangan Kesehatan, 11 (1 Mar).

Setiawan, E. 2014. Kamus Besar Bahasa Indonesia (KBBI) Online-Definisi Kata Interaktif.

Stang, M.E. 2011. Faktor yang Berhubungan dengan Pernikahan Dini di Kelurahan Pangli Kecamatan Sesean Kabupaten Toraja Utara. J MKMI, 7(1), pp.105-10.

Supriyati, N. 2011. Pengaruh Perkawinan Dini Terhadap Perilaku Pasangan Suami Istri di Desa Pepe Kecamatan Tegowanu Kabupaten Grobongan. Skripsi. Universitas Institut Keguruan Dan Ilmu Pendidikan.

Survei Demografi dan Kesehatan Indonesia (SDKI). 2007. Data Pernikahan Dini Di Indonesia. Jakarta: Depkes RI.

Syulasmi, A., Sihombing, P., Amprasto, M. and Fitriani, A. 2001. Pembelajaran Pengetahuan Lingkungan Menggunakan Metode Pemecahan Masalah Atau Problem Solving Untuk Mahasiswa Tpb Di Jurusan Pendidikan Biologi. Jurnal Pengajaran MIPA, 2(2), pp.18-26.

Teti, S. 2012. Faktor-Faktor Penyebab Perkawinan di Bawah Umur di Desa Blandongan Kecamatan Banjarharjo Kabupaten Brebes. Skripsi. Yogyakarta Yanti, E., Kebidanan, F.K.D. 2012. Gambaran Pengetahuan Remaja Putri Tentang Risiko Perkawinan Dini Dalam Kehamilan Di Kelurahan Tanjung Gusta Lingkungan Ii Kecamatan Medan Helvetia Tahun 2012. Skripsi. Universitas Prima Indonesia Medan. 
262 The Indonesian Journal of Public Health, Vol. 12 No. 2, Desember 2017: 249-262

Yunita, A. 2014. Faktor-faktor yang berhubungan dengan kejadian pernikahan usia muda pada remaja putri di desa
Pagerejo Kabupaten Wonosobo. Jurnal Ilmiah STIKES Ngudi Waluyo Ungaran, Jawa Tengah. 